\title{
Rangeland governance in an open system: Protecting transhumance corridors in the Far North Province of Cameroon
}

\author{
Mark Moritz ${ }^{1 *}$, Bebisse Larisa Catherine ${ }^{2}$, Albert K Drent $^{3}$, Saïdou Kari ${ }^{4}$, Arabi Mouhaman $^{5}$ and Paul Scholte ${ }^{6}$
}

\begin{abstract}
The mobile pastoral system in the far north region of Cameroon is an excellent example of the paradox of pastoral land tenure, in that pastoralists need secure access to pasture and water, but also flexibility in resource use, i.e. the ability to move elsewhere because of spatio-temporal variation in resource availability. In this paper, we draw from our collective research and development experience with mobile pastoralists and discuss how non-governmental organisations have used ordinances and bureaucratic procedures to protect pastoral resources, in particular transhumance corridors that connect seasonal grazing lands in the far north region. We argue that the mobile pastoral system is best understood as an open system and explain what the implications are for the protection of pastoral resources. We argue that delimiting and protecting transhumance corridors is not the panacea, and we conclude with a discussion of the advantages and disadvantages of this approach.
\end{abstract}

Keywords: Pastoral systems; Rangeland governance; Common-pool resources; Transhumance corridors; Non-governmental organisations

\section{Introduction}

The mobile pastoral system in the Far North Province of Cameroon is an excellent example of what FernándezGiménez (2002) has referred to as the 'paradox of pastoral land tenure', in that pastoralists need secure access to pasture and water, but also flexibility in resource use, i.e. the ability to move elsewhere because of spatio-temporal variation in resource availability (Niamir-Fuller 1999; Turner 1999). Longitudinal, interdisciplinary studies of pastoral systems have shown that mobility is a key adaptation in pastoral systems (Behnke et al. 1993; Ellis and Swift 1988; McCabe 2004; Niamir-Fuller 1999) and that limitations on mobility often have disastrous consequences (Shahrani 2002).

In the Chad Basin, mobile pastoralists have the freedom to move within and between states, and the pastoral system is best described as an open system in which there are no social or natural boundaries (Moritz et al. 2013a). Pastoralists share an ethos of open access,

\footnotetext{
* Correspondence: mark.moritz@gmail.com

'Department of Anthropology, The Ohio State University, 174 W 18th Avenue, Columbus, OH 43210-1106, USA

Full list of author information is available at the end of the article
}

which prescribes that all pastoralists, regardless of class, ethnicity or nationality, have free access to commonpool grazing resources. Contrary to expectations, there is no evidence of a tragedy of the commons (Moritz et al. 2013b; Moritz et al. 2013a; Scholte et al. 2006). We have found indications that the system we describe for the Chad Basin is common in other pastoral systems in West Africa (Niamir-Fuller 1999), even when it is not labelled as such (Frantz 1986; Horowitz 1986; Stenning 1957; Swallow 1990), and it has also been described for pastoralists outside Africa (e.g. in Iran, Bradburd 1992).

One of the major threats to the common-pool grazing resources does not come from the pastoral system of open access, but from agricultural expansion onto seasonal grazing lands and the transhumance corridors connecting them (Galvin 2009; Moritz 2006a). One of the most common ways to protect pastoral resources and pastoralists' user rights of these resources from agricultural expansion is to designate agricultural and pastoral zones and delimit transhumance corridors. These solutions have been implemented at local as well as national levels in the forms of rural or pastoral codes (Hesse 2000). Niger's Rural Code is one example of national legislation that 
formally secured existing corridors and recognised pastoralists' user rights of grazing resources (IUCN 2011). While the focus in the literature has been on problems of implementation and governance of these rural codes (Flintan 2012; Hesse 2000; Tielkes et al. 2001), there has been less discussion of the conflict between the flexibility and openness of the pastoral system and the fixing and delimitation of resources and resource use through the delimitation of pastoral zones and transhumance corridors. In his discussion of governance of rangelands in West Africa, Turner (1999), however, has argued that there is a risk in formalising pastoral tenure institutions into rural codes where flexibility is more appropriate in terms of managing access to common-pool grazing resources in situations where there is considerable spatiotemporal variation in the distribution of these resources. The danger is that if tenure institutions become more formal and rigid, it will limit mobility with potentially negative consequences for the resilience of the socialecological system.

Here we discuss the conceptual framework of open systems that we have used to describe and explain the pastoral management of open access to common-pool grazing resources (Moritz et al. 2013a) and its implications for the governance of rangelands and pastoral infrastructure in West Africa and beyond, with a particular focus on the protection of transhumance corridors that allow mobile pastoralists to move between seasonal grazing areas.

We have been conducting research on different pastoral systems in the Chad Basin for the last 20 years (Moritz 2008; Moritz et al. 2013a; Moritz et al. 2010; Scholte et al. 2006), and our discussion here draws from our involvement in pastoral development in the far north region in different capacities. Two of the authors worked for the Waza Logone Project in the 1990s (PS, SK), two others are currently members of Centre d'Appui à la Recherche et au Pastoralisme (CARPA) (SK, AM), one studied the process of delimiting the transhumance corridor as an intern at CARPA (BLC), and two others have studied different pastoral systems in the Far North Province, including pastoral development (MM, AD).

\section{Study area}

\section{Mobile pastoralists in the Far North Province of Cameroon}

The Far North Province of Cameroon has one of the highest population densities in the country and is characterised by a great diversity in ethno-linguistic groups and a mosaic of different agricultural and pastoral systems, which have been integrated at the household, community and regional level for centuries (Moritz 2010; Seignobos and Iyébi-Mandjek 2000). One could describe the grazing lands as fragmented (Galvin et al. 2008), but the grazing lands have historically always been part of a mosaic of different forms of land use in the far north region (Seignobos and Iyébi-Mandjek 2000). Moreover, there is considerable spatial variation in population densities and forms of land use (see also Raynaut 2001). Pastoralists have been able to exploit common-pool grazing resources across the region by using transhumance corridors to move between areas with lower population densities, including the key resource area of the Logone floodplain. However, in the last decades, there has been increasing pressure on grazing lands as well as on the corridors linking the seasonal grazing areas due to demographic pressures and economic development (Moritz 2008).

The cattle population in the Far North Province is significant and has been estimated at 2.1 million and the small stock population at 2.8 million (Ziébé et al. 2005). Animal husbandry provides subsistence and a significant source of income for a large part of the rural population, including peri-urban pastoralists, agro-pastoralists and mobile pastoralists (Moritz 2012). The population of mobile pastoralists consists of different groups of Suwa Arabs and FulBe, in which the latter consists of different sub-ethnic groups like the Jamaare, Mare, Uuda, Alijam, Adanko and Anagamba, which are more or less endogamous and have their own dialect, cattle breed, house types and marriage system. Pastoralists in the region have been incorporated in the market economy for centuries and are linked to extensive livestock trade networks that cross the Chad Basin (Kerven 1992; Moritz 2003). However, pastoral systems have remained primarily subsistence-orientated rather than capitalist-orientated. Pastoralists sell animals when they have a need; their production goal is not to maximise profits (Moritz 2012).

Pastoral mobility is driven by seasonal variations in rainfall, which results in spatio-temporal variation in pastoral resources: forage and water. FulBe pastoralists in the far north region talk about four distinct seasons when they discuss their mobility patterns. The rainy season (duumol) runs from July through September with the main rains in July and August (loDDo). It is followed by the cold dry season (daBBunde) from October to January and the hot dry season (ceedu) from March to May. June is a transition season (seeto) from dry to rainy season. One of the key resource areas in the region is the Logone floodplain (Scholte and Brouwer 2008), called Yaayre in Fulfulde, which is flooded by the Logone River and its branches from September until November (see Figure 1). After the water recedes in December, thousands of Arab and FulBe pastoralists from Cameroon, Nigeria and Niger move with more than 200,000 cattle into the floodplain, making it one of the most important dry season grazing lands in the Chad Basin (Seignobos and Iyébi-Mandjek 2000). Many pastoralists remain there until the start of the rainy season, while most move either further north into the floodplain 


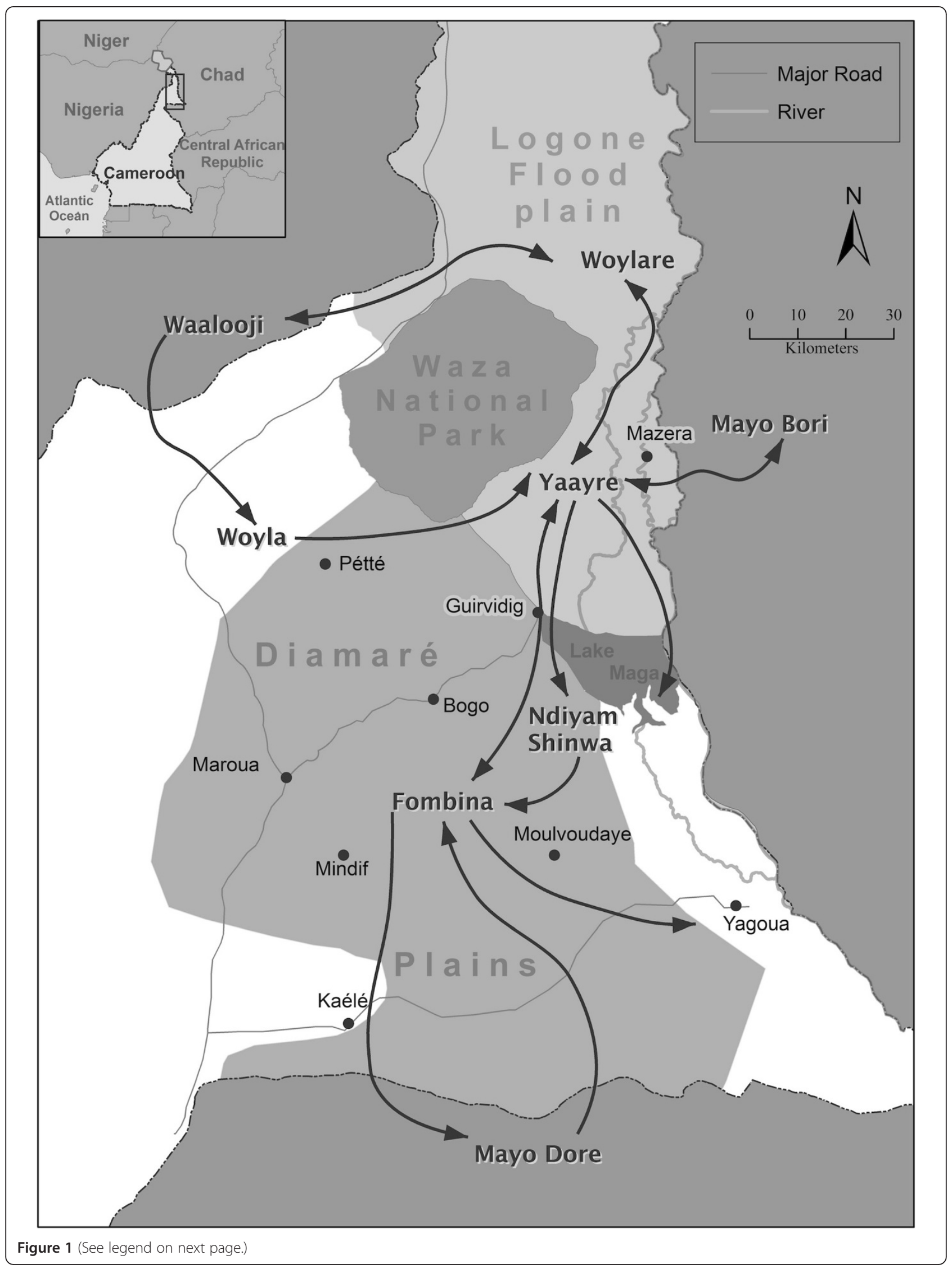


Figure 1 The Far North Province of Cameroon. The arrows broadly indicate the general direction of the transhumance orbits of mobile pastoralists in our study area of the Logone floodplain and the Diamaré Plains. There are currently no maps showing the pastoral infrastructure of campsites, watering points and transhumance corridors (even though they are visible on satellite images, including Google Earth).

or south to the grazing lands that surround Lake Maga. Pastoralists find nutritious regrowth and surface water in the floodplain far into the dry season, when surrounding pastures have dried up. At the start of the rainy season, pastoralists return to the higher elevated dunes of the Diamaré or their respective countries. In the far north region, there is an extensive network of 'invisible' pastoral infrastructure that includes campsites, watering points and transhumance corridors and allows mobile pastoralists to exploit the spatio-temporal variation in resources.

\section{Pastoral infrastructure}

Pastoral infrastructure is critical for supporting pastoral mobility in this open system, in particular transhumance corridors that allow pastoralists to move between seasonal grazing areas and exploit the spatio-temporal variation in forage throughout the Chad Basin. However, one of the problems is that the infrastructure of mobile pastoralists is often invisible because they do not remain in one location throughout the year and do not leave many traces. For example, despite decades of geographic research (Boutrais 1984; Frechou 1966; Seignobos and Iyébi-Mandjek 2000), there are no traces of mobile pastoralists on maps or atlases. Instead their movements are indicated with broad arrows (as in the example in Figure 1). This invisibility is problematic because the existing pastoral infrastructure is often not recognised or protected, which allows farmers to convert campsites and transhumance routes into fields.

As part of a longitudinal, interdisciplinary study that examines how mobile pastoralists manage common-pool grazing resources, we have used GPS/GIS technology to document pastoral mobility as well as the infrastructure used to move within and between seasonal grazing areas, such as campsites, watering points and transhumance corridors (Moritz et al. 2010).

\section{Campsites}

Mobile pastoralists often return to the same campsite in a particular seasonal grazing area year after year. They set up their houses and corrals in these sites and their herds forage the surrounding pastures. The campsites are often slightly elevated and cleared from vegetation to protect humans and animals and close to a permanent water source for the young calves that stay behind in the camp during the day. Because pastoralists return to the same campsites over the years, cattle dung accumulates in the corrals, which makes them attractive sites for farmers who seek to clear new fields for their crops. There are two kinds of campsites: transit and sojourn campsites. Transit campsites are found along transhumance corridors and used to move from one seasonal grazing area to another. Pastoralists only stay for one to three days in these campsites. Sojourn campsites are located in seasonal grazing areas and pastoralists spend up to three to six months in these sites.

\section{Watering points}

Access to water is critical for livestock in the dry season in arid and semi-arid rangelands. In the floodplain, most watering places are natural and thus open for all - rivers, depressions, lakes - and located throughout the floodplain, while the artificial lakes dug by the Lake Chad Basin Commission (LCBC) are explicitly open for all pastoralists from the member states (Moritz et al. 2013a). During the rainy season when mobile pastoralists are outside the floodplain, they find water in small, natural ponds throughout their grazing areas.

\section{Transhumance corridors}

When mobile pastoralists move with their animals to the Logone floodplain in October, they use a network of transhumance corridors that connect their rainy season grazing areas in the Diamaré to the dry season grazing areas of the floodplain (see Figure 1). Along these corridors, there are watering points and transit campsites where pastoralists stay overnight for a day or two before they move on. The corridors transect densely populated agricultural areas, and one of the main threats to pastoral mobility has been the expansion of agricultural fields onto these corridors.

These campsites, watering points and transhumance corridors are critical for sustainable management of rangelands because they allow pastoralists to move between and camp within seasonal grazing areas in the far north region of Cameroon as well as the larger Chad Basin. Below we will discuss how development organisations have attempted to delimit and protect these infrastructures in the far north region of Cameroon. But first we will describe pastoralists' use of these infrastructures and how they support the open pastoral system in the Chad Basin.

\section{Open access, open systems in the Chad basin}

Mobile pastoralists in the region share a strong ethos of open access to common-pool grazing resources. They believe that every pastoralist has the same rights to use grazing lands, regardless of ethnicity, nationality, seniority or socio-economic status. Pastoralists emphatically argue 
that access is free and open for everyone; it does not matter whether pastoralists are coming from Cameroon or Nigeria, whether they are newcomers or old-timers or whether they are FulBe or Arab. When asked about open access, pastoralists would say as a matter of fact, na'i non, naa yimBe 'it's [about] cattle, not [about] people', or nagge nyaamataa nagge 'cattle do not eat [other] cattle', meaning all cattle are equal and have equal access to the pastures (Moritz et al. 2013a). For mobile pastoralists, keeping cattle is not only a way of making a living and a way of life, but one could argue that cattle are life because without them people cannot live as pastoralists. In this sense, to deny cattle access to grazing resources is to deny pastoralists life. This ethos of open access, which is shared among all mobile pastoralists in our study area, including absentee owners and their hired herders, informs how pastoralists coordinate their movements and use of common-pool grazing resources (Moritz et al. 2013a).

Although pastoralists gain customary rights over campsites after two or three years of consecutive seasonal occupation, these rights do not give pastoralists exclusive access over the common-pool grazing resources surrounding the campsite. Thus, access to grazing lands is open, even when pastoralists have customary rights to campsites within these grazing lands. No one is obliged to ask for permission from traditional or governmental authorities or other pastoralists to set up camp near established campsites. This applies to all pastoralists, including newcomers from other groups or countries. Pastoralists may ask fellow pastoralists whether they can set up camp close by, but this request cannot be refused. Moreover, many pastoralists do not ask out of principle or inform their neighbours about site decisions, not even when they set up camp $250 \mathrm{~m}$ from another campsite. These rules are not limited to the floodplain; they also apply to the rainy season grazing areas in the Diamaré.

We have referred to this system as management of open access (Moritz et al. 2013a), which we argue is not an oxymoron because there are clear rules about who has access to the common-pool grazing resources (all pastoralists) and who can be excluded (no one). The rules are reaffirmed in everyday practice every time pastoralists set up camps in new sites without asking. The ethos and practice of open access is a form of everyday management that regulates the use of common-pool resources in that there are two important outcomes: the emergence of an ideal-free-like distribution of mobile pastoralists in which the distribution of grazing pressure matches the distribution of grazing resources (Moritz et al. 2013b; Moritz et al. 2013c) and the lack of major conflict among pastoralists (Scholte et al. 2006). These outcomes require the everyday commitment of pastoralists to the ethos and practice of open access. Pastoralists themselves talk about open access not in terms of an absence of rules but in terms of rights for all. Moreover, these rules are meaningful to mobile pastoralists - without access to common-pool grazing resources, they cannot survive in this semi-arid environment (Moritz et al. 2013a).

In addition, the pastoral system in the far north region is also an open system in the sense that there are no social or ethnic boundaries. All who are committed to mobile pastoralism, in which the needs of animals are central, are members of the user group. And while there are distinct ethnic groups among pastoralists, these groups are not territorial, and the ethnic boundaries are permeable as people 'enter' ethnic groups that they share transhumance routes with (see also Bradburd 1992).

\section{Legal and institutional context of rangeland governance}

Central governments in the Chad Basin have generally been supportive of pastoralists' mobility and have guaranteed their open access to common-pool grazing resources. First, current laws support open access to common-pool grazing resources. Second, national and international policies protect transhumance corridors that allow pastoralists to move between seasonal grazing areas in the Chad Basin.

Grazing lands in Cameroon are legally state property (Ordinance No. 74-1 of 1974). However, the law explicitly gives all pastoralists the right to use these common-pool resources, unless the state uses these grazing lands for other purposes such as wildlife conservation or agricultural development projects. National laws thus support pastoralists' open access to grazing lands; provided pastoralists vaccinate their animals and pay their taxes, they cannot be denied access to these common-pool grazing resources.

In addition, the LCBC has been supporting the system of open access to common-pool grazing resources since its creation in the 1960s, by the four countries bordering Lake Chad: Cameroon, Chad, Niger and Nigeria. The member countries recognise the importance of livestock for the economy in the Chad Basin, and its primary concerns are coordination of veterinary controls and facilitating livestock trade (and thus livestock movements) between countries. In addition, the commission aims to regulate and control the use of water and other natural resources in the basin and to initiate, promote and coordinate natural resource development projects and research. International agreements between Lake Chad Basin Commission member countries enable freedom of movement for pastoralists in the Chad Basin, provided they have vaccinated their animals and paid the local and national taxes. This allows pastoralists from Chad, Niger, Nigeria, Cameroon and more recently the Central African Republic and Sudan which joined the LCBC to travel freely within the Chad Basin if they can show their certificate of vaccination and tax receipts. 
While there are no specific laws concerning pastoralists' use of grazing lands in Cameroon, there are a number of decrees and ordinances that are currently used by organisations working with mobile pastoralists to protect grazing lands and transhumance corridors within the far north region. The most important and most widely used decree concerns the resolution of conflicts between agricultural and pastoral uses of land (no. 78-263). The decree specifies the procedures for settling agro-pastoral disputes at the local or district level, as well as how the committee works that is in charge of organising the agricultural and pastoral spaces. A number of the activities of these local committees are delimiting agricultural and pastoral zones, enforcing the boundaries of these zones, designating transhumance corridors, taking measures to avoid land use conflicts and resolving conflicts between agricultural and pastoral uses of land.

There are some indications that Cameroon is moving towards a comprehensive 'pastoral code' that would describe and regulate pastoral use of grazing lands, but this new law has not been voted on yet, and so most organisations working to protect pastoral infrastructure have used the decree concerning the resolution of agro-pastoral conflicts (No. 78-263) to achieve their goals.

\section{Protection of transhumance corridors}

In the last 20 years, development and other nongovernment organisations have used the decree for settling agro-pastoral conflicts (No. 78-263) to delimit and protect the pastoral infrastructure in the far north region of Cameroon. For example, at the end of the 1990s, an international development organisation, the Waza Logone Project (IUCN), designated pastoral and agricultural zones and delimited transhumance corridors that pastoralists use to enter the Logone floodplain at the beginning of the dry season (Kari and Scholte 2001). The Waza Logone Project's main role was to motivate and organise the different stakeholders including pastoralists, agriculturalists and traditional and governmental authorities, to delimit and protect (through consensus) transhumance corridors, overnight campsites and pastoral zones. The protection of the pastoral infrastructure was critical because it concerned an important bottleneck in the network that was used by between 50,000 and 100,000 cattle every year. Since then the same process has been used by a number of Cameroonian non-governmental organisations advocating for pastoralists to protect other transhumance corridors and pastoral zones, in particular the Fédération des Eleveurs des Bovins (FEB) and the CARPA. Today about $150 \mathrm{~km}$ of transhumance corridors has been protected through this process, although this is still less than $10 \%$ of the transhumance corridors in the region.

Most recently, CARPA led the effort to protect another critical transhumance corridor that mobile pastoralists take to move to the Logone floodplain (Bebisse 2011). The corridor was blocked by a forest created by the Cameroonian government. CARPA brought all the stakeholders together, i.e. everyone with an interest in agro-pastoral conflicts, which included representatives from the agricultural and pastoral communities, representatives of the different government services (e.g. veterinary services, police), traditional authorities of all the villages along the corridor, municipal authorities (e.g. mayor and council members) and the government authorities (e.g. district head or sous-préfet). The process involved surveying the corridor, identifying conflicts along the corridor, signing an agreement, delimiting the corridor with cement markers and the creation of a local oversight (or management) committee to continue dialogue between the different user groups and support the participatory management of the corridors (Bebisse 2011).

As there are various conflicts of interest between the different stakeholders - the most important ones being political conflicts between the traditional and governmental authorities (Moritz 2006b) - the process takes considerable time and negotiation. Part of the problem is the situation of legal pluralism in which national laws are often trumped by traditional practices. For example, while the district chief (sous-préfet) is officially in charge of land rights, in practice, traditional authorities are the ones allocating land rights and adjudicating in conflicts over land in the far north region (Teyssier et al. 2003). This adds to the challenges of bringing the stakeholders together and getting them to agree on the delimitation of the corridors.

The process is also relatively expensive, not so much because of the hundreds of cement markers but because of the costs of getting everyone to the field, which includes per diem for the different officials as well as transportation costs (often a euphemism for informal payments). While local non-governmental organisations have been responsible for the organisation of the process and the negotiations between the different stakeholders, the financial support has primarily come from outsiders, in particular research and development organisations interested in protecting pastoral mobility (including our own research projects). The reliance on external funds also raises questions about the sustainability of these interventions. Due to the nature of the development funding cycle - e.g., limited funds, short duration, pressure for immediate and tangible results, uncertainty of renewal - there is often no meaningful participation and investment of the local stakeholders (Igoe 2004). What then remains of these projects are the physical cement markers but no sustainable solution to the problem of conflicting land uses (Catley et al. 2013).

However, pastoralists have also initiated the process and raised funds themselves. For example, mobile pastoralists 
have approached the traditional chief of Kolora, someone who has advocated often on behalf of mobile pastoralists, and CARPA to help them protect the corridor KoloraKobo-Horlong, which is a $16-\mathrm{km}$ track in the overall network of transhumance corridors and used by a relatively small number of camps and households. The pastoralists also succeeded in securing access to an artificial lake for watering cattle near Kobo and a prohibition of cultivation within a $1.5-\mathrm{km}$ radius of the lake. In the agreement, the parties also designated agricultural and pastoral zones in order to prevent encroachment of farms and fields into grazing lands. The total costs were 2.5 million FCFA or about US $\$ 5,000$, of which $80 \%$ came from pastoralists themselves, with $20 \%$ of matching funds from our research project.

The protection of transhumance corridors described above is no panacea. The process is not finished with the delimitation of the corridors and the creation of oversight committees. Despite the protection, oversight committees and cement markers, there continues to be encroachment of fields onto the grazing areas, campsites and transhumance corridors. One of the reasons why the delimitation of corridors currently does not offer a permanent solution is that the use of the decree for settling agro-pastoral conflicts (No. 78-263) to delimit the corridors and pastoral zones does not give them legal protection. This is only achieved when the governor or the divisional officer (préfet) signs an administrative act (arrêté) that specifies that the delimited grazing lands or corridors be exclusively reserved for pastoral use. With an administrative act, trespassers can be taken to court; without an administrative act, the only recourse is arbitration between the parties by the agro-pastoral committee. This means that continuous follow-up by advocates of mobile pastoralists, e.g. CARPA and FEB, is necessary to prod the authorities into action when there are problems along the corridors. The transhumance corridor delimited by the Waza Logone Project in the 1990s, for example, is still there, but fields have slowly expanded and now there is no longer the legally required clearance of $25 \mathrm{~m}$ on each side. The cement markers have disappeared or are located in sorghum fields.

Local organisations like CARPA, FEB and the Observatoire du Pastoralisme dans l'Extrême-Nord are focusing their efforts on educating stakeholders and other authorities about pastoral systems and the importance of mobility, developing and promoting new laws and policies for sustainable management of pastoral resources. In addition, they encourage the participation of pastoralists in the management of pastoral resources and infrastructure. The limitations of the current approach are that it is primarily driven by the organisations that work on behalf of mobile pastoralists. Pastoralists attend the process, but they are not taking an active role. One of the main reasons is that very few mobile pastoralists in the far north region have any formal education. They do not speak the official languages (French, English) and do not have a good understanding of the laws and bureaucratic processes. The situation in the far north is very different from the northwest of Cameroon, which has a long tradition of pastoralists receiving formal education and pastoralists organising themselves in advocacy groups like the Mbororo Social and Cultural Development Association (Davis 1995; Pelican 2008). The problem is not limited to pastoralists attending the process; farmers were also not well represented and implicated in the process of delimiting the corridors. We observed heated discussions between farmers and the authorities during their visits to the field as the former felt excluded from the process (Bebisse 2011). The limited involvement of both pastoralists and farmers in the process has implications for the sustainability of the existing infrastructures.

\section{Discussion: Governance of open systems}

What are the implications of management of open systems (Moritz et al. 2013a) for the governance of pastoral infrastructure and in particular the protection and delimitation of transhumance corridors?

First, because we are dealing with an open system in which mobile pastoralists are not bounded to one particular place, the protection of pastoral resources and infrastructure should be for all pastoralists (and not just for current users), and all pastoralists should have the right to use the associated infrastructure of campsites, watering points and transhumance corridors. Because mobile pastoralists in the Chad Basin operate in an open system, it is critical that mobility is supported at the supra-national level of the Lake Chad Basin Commission as well as the national, regional and local levels. However, currently there is a tension between laws and policies at the national and supra-national level, which support pastoral mobility in an open system, and its implementation at the local and regional levels. The interests at the national and supranational level, in support of pastoral mobility, are often not aligned with those at the regional and local levels, where there are governmental as well as traditional authorities with primarily agricultural constituencies. For example, at the national level, authorities benefit from the free movement of cattle because of taxes and other levies on pastoralists and livestock traders, whereas at the local level, authorities derive most of their income from agricultural populations.

Second, the delimitation of corridors has the potential to reduce pastoralists' flexibility in mobility. The annual transhumance movements between the rainy season grazing lands in the Diamaré plains and the dry season grazing lands in the Logone floodplain have a long history, going back at least 60 years (Mouchet 1960). But the 
routes that pastoralists took to reach the floodplain have changed considerably in that period (and continue to change) following major land use changes along these routes. For pastoralists, it is most critical to be able to move from one seasonal grazing area to another, and the corridors are primarily a means to an end. The recent history of transhumance corridors shows that while some corridors are being closed off, new ones are opening up. Transhumance orbits change over time because of social and ecological reasons and so do the transhumance corridors that take pastoralists to different seasonal grazing areas in the Chad Basin.

The infrastructure of transhumance corridors in the far north region of Cameroon, where we conduct our research, reflects the openness and flexibility of this pastoral system as it facilitates the movements within and between seasonal grazing areas. Recognising the importance of mobility for sustainable development of pastoral systems, development organisations working with mobile pastoralists have engaged in several projects in which transhumance corridors were delimited and demarcated, as we described above. However, the protected status has not prevented encroachment on these routes; cement markers delimiting the corridors are now located in sorghum fields. In response, pastoralists are using new routes, which they claim are sometimes better than the ones that they lost.

Third, it is also important to realise that the delimitation of corridors has its own set of problems because it fixes not only the infrastructure but also the institutions that govern these infrastructures. In some ways, the process of delimitation of corridors and pastoral zones gives pastoralists a sense of entitlement to particular corridors or grazing areas, which makes them more likely to appeal to the authorities and the oversight committees to resolve conflicts, whereas they used to be more flexible in their resolution of conflicts in the past (Drent, in preparation). The appeal to authorities often has the opposite effect and leads to permanent conflict that is perpetuated by the authorities seeking rents from both herders and farmers (Moritz 2006b). More importantly, the involvement of authorities reduces the options for local user groups of herders and farmers to find their own negotiated and flexible low-stakes solutions for the conflicts that are inherent to the mosaic of land use characteristic of the Sahelian and Sudanian zones of West and Central Africa. In their comparison of herder-farmer conflicts in northwest Cameroon and Burkina Faso, Dafinger and Pelican (2006) observed a similar phenomenon. After the creation of agricultural and pastoral zones in northwest Cameroon, the number of disputes decreased but their intensity increased, and they tended to escalate to larger conflicts. Dafinger and Pelican (2006) argued that the creation of land use zones reduced daily negotiations between herders and farmers and their ability to resolve them without involvement of the authorities. We see similar developments in the far north region of Cameroon, with the protection of transhumance corridors.

We have argued that while it is important to protect pastoralists' rights of access to grazing resources in an open system, this is not the same as delimiting pastoral infrastructures. This is one of the key lessons of the 'paradox of pastoral land tenure' - pastoralists' need of secure access to pasture and water but also flexibility in resource use (Fernández-Giménez 2002). The critical lesson here is that governance should be focused on supporting the flexibility of pastoral mobility in an open system, and this is not achieved by mapping, fixing and delimiting the corridors, which may even have the opposite effect. The desire to map, fix and delimit the 'invisible pastoral infrastructure' is an example of what the political scientist James Scott has described as modernist legibility project in his book Seeing Like a State (Scott 1998). One of the assumptions guiding development projects, including our own previous efforts, is that the invisibility is a problem and that by mapping and delimiting the infrastructure - making it visible and legible - transhumance corridors can be protected. However, we argue that these legibility projects have their own limitations because it fixes infrastructures and institutions where flexibility in movements and conflict resolution are more appropriate.

What is then our proposed approach? How to protect pastoralists' rights to resources as well as their freedom to move? The protection of seasonal grazing areas and transhumance corridors is still important. But rather than thinking about the delimitation of zones and corridors as the end of the process (or conversation), it may be more useful to think of the delimitation as the means of the process or the start of a conversation about the management of common-pool resources. In this view, the protection and delimitation of one particular transhumance corridor is not a permanent solution; it is an argument for pastoralists' user rights in a broader conversation about the management of common-pool resources. In this conversation, there will be counter-arguments and the likely result is that the path of the corridor will likely change. However, the end goal for pastoralists in this conversation is not to protect particular resources but to protect their general user rights and their freedom to move.

\section{Competing interests}

The authors declare that they have no competing interests.

\section{Authors' contributions}

The manuscript is the product of a long-term collaboration and draws on our respective research projects with pastoralists in the far north region of Cameroon. MM wrote the first draft and we edited the manuscript as a team. All authors read and approved the final manuscript. 


\section{Authors' information}

MM is an anthropologist and involved in several longitudinal, transdisciplinary research projects that examine pastoral systems within the analytical framework of coupled human and natural systems. BLC has an MA in social sciences specialising in development and conflict resolution. She studied land use conflicts and protection of transhumance corridors in Bogo, Cameroon. AD is a Ph.D. candidate at the Max Planck Institute for Social Anthropology. His research interests are legal anthropology, conflict studies, pastoralism, ecology and resource management. SK is a Co-Director of the Center for Support to Research and Pastoralism (CARPA) and has years of experience working in pastoral development in the Far North of Cameroon. MA is a development planning and environmental management expert currently a Lecturer at the Department of Environmental Sciences, Higher Institute of the Sahel at the University of Maroua and pursuing his Ph.D. in Geography. He is also Co-Director of the Center for Support to Research and Pastoralism (CARPA). PS is an ecologist, specialised in conservation in a development context, in protected area and rangeland management, biodiversity inventories, governance, rural development, ecotourism, training and education. He has experience with the management, formulation and evaluation of programs in the main global ecosystems.

\section{Acknowledgements}

This research has been supported by the National Science Foundation (BCS0748594), the National Geographic Society (8306-07), and the Division of Social and Behavioral Sciences and the Anthropology Department at the Ohio State University. We want to thank the Ministry of Scientific Research and Innovation (MINRESI), the Ecole de Faune de Garoua and the University of Maroua for granting research permission and research affiliation.

\section{Author details}

'Department of Anthropology, The Ohio State University, 174 W 18th Avenue, Columbus, OH 43210-1106, USA. ²Department of Social Sciences, University of Maroua, Maroua BP 46, Cameroon. ${ }^{3}$ Max Planck Institute for Social Anthropology, Advokatenweg 36, Halle 06114, Germany. ${ }^{4}$ Center for Support to Research and Pastoralism (CARPA), Maroua BP 383, Cameroon. ${ }^{5}$ Department of Environmental Sciences, University of Maroua, Maroua BP 46, Cameroon. ${ }^{6}$ Nieuwe Teertuinen 12c, Amsterdam 1013 LV, The Netherlands.

Received: 5 May 2013 Accepted: 22 August 2013

Published: 4 October 2013

\section{References}

Bebisse, L. 2011. Gestion des conflits fonciers, mobilite patorale et securisation des pistes de transhumance: Cas du projet de securisation de la piste de transhumance de bogo dans l'extreme-nord du Cameroun. MA thesis: University of Maroua.

Behnke, RH, I Scoones, and C Kerven (eds.). 1993. Range ecology at disequilibrium: New models of natural variability and pastoral adaptation in African savannas. London: Overseas Development Institute.

Boutrais, J (ed.). 1984. Le Nord du Cameroun: Des hommes, une région. Paris: ORSTOM.

Bradburd, DA. 1992. Territoriality and Iranian pastoralists: Looking out from Kerman. In Mobility and territoriality: Social and spatial boundaries among foragers, fishers, pastoralists, and peripatetics, ed. M.J. Casimir and A. Rao, 309-327. New York: Berg.

Catley, A, J Lind, and I Scoones. 2013. Development at the margins: Pastoralism in the Horn of Africa. In Pastoralism and development: Dynamic change at the margins, ed. A. Catley, J. Lind, and I. Scoones, 1-26. London: Routledge and Earthscan.

Dafinger, A, and M Pelican. 2006. Sharing or dividing the land? Land rights and herder-farmer relations in Burkina Faso and Northwest Cameroon. Canadian Journal of African Studies 40: 127-151.

Davis, L. 1995. Opening political space in Cameroon: The ambiguous response of the Mbororo. Review of African Political Economy 22: 213-228.

Ellis, JE, and DM Swift. 1988. Stability of African pastoral ecosystems: Alternative paradigms and implications for development. Journal of Range Management 41: 450-459.

Fernández-Giménez, ME. 2002. Spatial and social boundaries and the paradox of pastoral land tenure: A case study from postsocialist Mongolia. Human Ecology 30: 49-79.
Flintan, F. 2012. Protecting livestock mobility routes: Lessons learned. Rome: International Land Coalition.

Frantz, C. 1986. Fulani continuity and change under five flags. In Pastoralists of the West African savanna, ed. M. Adamu and A.H.M. Kirk-Greene, 16-39. Manchester: Manchester University Press.

Frechou, H. 1966. L'elevage et le commerce du betail dans le nord du Cameroun. Paris: ORSTROM.

Galvin, KA. 2009. Transitions: Pastoralists living with change. Annual Review of Anthropology 38: 185-198.

Galvin, KA, RS Reid, RH Behnke, and NT Hobbs (eds.). 2008. Fragmentation in semi-arid and arid landscapes consequences for human and natural landscapes. Dordrecht: Springer.

Hesse, C. 2000. Gestion des parcours: Qui en est responsable et qui y a droit? In Elevage et gestion de parcours au Sahel, implications pour le développement, ed. E. Tielkes, E. Schlecht, and P. Hiernaux, 139-153. Stuttgart: Grauer.

Horowitz, MM. 1986. Ideology, policy, and praxis in pastoral livestock development. In Anthropology and rural development in West Africa, ed. M.M. Horowitz and T.M. Painter, 251-272. Boulder: Westview.

Igoe, J. 2004. Conservation and globalization: A study of national parks and indigenous communities from East Africa to South Dakota. Belmont: Wadsworth/Thompson Learning.

IUCN. 2011. The land we graze: A synthesis of case studies about how pastoralists' organizations defend their land rights. Nairobi: IUCN ESARO.

Kari, S, and P Scholte. 2001. La réhabilitation pastorale de la plaine d'inondation waza-logone (Cameroun): Comment consolider sa réussite écologique? In Atelier regional: Les approches de la gestion des pâturages et les projets de développement: Quelles perspectives? ed. E. Tielkes, E. Schlecht, and P. Hiernaux, 315-316. Niamey: Grauer

Kerven, C. 1992. Customary commerce: A historical reassessment of pastoral livestock marketing in Africa, vol. 15. ODI agricultural occasional paper. London: Overseas Development Institute.

McCabe, JT. 2004. Cattle bring us to our enemies: Turkana ecology, politics, and raiding in a disequilibrium system. Ann Arbor: Michigan University Press.

Moritz, M. 2003. Commoditization and the pursuit of piety: The transformation of an African pastoral system. Dissertation: University of California at Los Angeles.

Moritz, M. 2006a. Changing contexts and dynamics of farmer-herder conflicts across West Africa. Canadian Journal of African Studies 40: 1-40.

Moritz, M. 2006b. The politics of permanent conflict: farmer-herder conflicts in Northern Cameroon. Canadian Journal of African Studies 40: 101-126.

Moritz, M. 2008. Competing paradigms in pastoral development? A perspective from the Far North of Cameroon. World Development 36: 2243-2254.

Moritz, M. 2010. Crop-livestock interactions in agricultural and pastoral systems in West Africa. Agriculture and Human Values 27: 119-128.

Moritz, M. 2012. Pastoral intensification in West Africa: Implications for sustainability. Journal of the Royal Anthropological Institute 18: 418-438.

Moritz, M, E Soma, P Scholte, T Juran, L Taylor, S Kari, and N Xiao. 2010. An integrated approach to modeling grazing pressure in pastoral systems: The case of the Logone floodplain (Cameroon). Human Ecology 38: 775-789.

Moritz, M, P Scholte, IM Hamilton, and S Kari. 2013a. Open access, open systems: Pastoral management of common-pool resources in the Chad Basin. Human Ecology 41: 351-365.

Moritz, M, IM Hamilton, P Scholte, and Y-J Chen. 2013b. Ideal free distributions of mobile pastoralists within multiple seasonal grazing areas. Journal of Arid Environments. in press.

Moritz, M, IM Hamilton, Y-J Chen, and P Scholte. 2014. Mobile pastoralists in the Logone Floodplain distribute themselves in an Ideal Free Distribution. Current Anthropology 55

Mouchet, J. 1960. Enquête entomologique dans le Logone et Chari (13-25 ma 1960). I: Le Foyer de glossines du Logone et Chari. II: L'Anophélisme et les possibilités de lutte antipaludique. III: La Transhumance des "Foulbé" dans les "yaéré". Paris: IRCAM

Niamir-Fuller, M. (ed.). 1999. Managing mobility in African rangelands: The legitimization of transhumance. London: Intermediate technology.

Pelican, M. 2008. Mbororo claims to regional citizenship and minority status in North-West Cameroon. Africa. The Journal of the International African Institute 78: $540-560$

Raynaut, C. 2001. Societies and nature in the Sahel: Ecological diversity and social dynamics. Global Environmental Change 11: 9-18.

Scholte, P, and J Brouwer. 2008. The relevance of key resource areas for largescale movements of livestock: Developing the KRA-concept based on examples from Sahelian floodplains. In Resource ecology: Spatial and temporal 
aspects of foraging, ed. H.H.T. Prins and F.v. Langevelde, 211-232. Wageningen: Springer.

Scholte, P, S Kari, M Moritz, and H Prins. 2006. Pastoralist responses to floodplain rehabilitation in Northern Cameroon. Human Ecology 34: 27-51.

Scott, JC. 1998. Seeing like a state: How certain schemes to improve the human condition have failed. Yale agrarian studies. New Haven: Yale University Press.

Seignobos, C, and O lyébi-Mandjek (eds.). 2000. Atlas de la Province Extrême-Nord Cameroun. Paris: IRD \& MINREST.

Shahrani, MN. 2002. The Kirghiz and the Wakhi of Afghanistan: Adaptation to closed frontiers and war, 2nd ed. Seattle: University of Washington Press.

Stenning, DJ. 1957. Transhumance, migratory drift, migration: Patterns of pastoral Fulani nomadism. The Journal of the Royal Anthropological Institute of Great Britain and Ireland 87: 57-73.

Swallow, BM. 1990. Strategies and tenure in African livestock development. LTC paper \#140. Madison: Land Tenure Center, University of Wisconsin.

Teyssier, A, O Hamadou, and C Seignobos. 2003. Expériences de médiation foncière dans le Nord-Cameroun, 90-115. Land Reform.

Tielkes, E, E Schlecht, and P Hiernaux (eds.). 2001. Elevage et gestion de parcours au Sahel: Implications pour le développement. Comptes-rendus d'un atelier régional ouest-Africain sur "La gestion des pâturages et les projets de développement: Quelles perspectives?" qui s'est tenu du 2 au 6 Octobre 2000 à Niamey, Niger. La gestion des pâturages et les projets de développement: Quelles perspectives? Stuttgart: Grauer.

Turner, MD. 1999. The role of social networks, indefinite boundaries and political bargaining in maintaining the ecological and economic resiliency of the transhumance systems of Sudano-Sahelian West Africa. In Managing mobility in African rangelands, ed. M. Niamir-Fuller, 97-123. London: IT.

Ziébé, R, E Thys, and R De Deken. 2005. Analyse de systèmes de production animale à l'échelle d'un canton: Cas de Boboyo dans l'Extrême-Nord Cameroun. Revue D'élevage et de Médecine Véterinaire des Pays Tropicaux 58: 159-165.

doi:10.1186/2041-7136-3-26

Cite this article as: Moritz et al:: Rangeland governance in an open system: Protecting transhumance corridors in the Far North Province of Cameroon. Pastoralism: Research, Policy and Practice 2013 3:26.

\section{Submit your manuscript to a SpringerOpen ${ }^{\circ}$ journal and benefit from:}

- Convenient online submission

- Rigorous peer review

- Immediate publication on acceptance

- Open access: articles freely available online

- High visibility within the field

- Retaining the copyright to your article

Submit your next manuscript at $\gg$ springeropen.com 